\title{
INVESTIGATION OF POLAR SNOW USING SEISMIC VELOCITY GRADIENTS*
}

\author{
By James D. Robertson and Charles R. Bentley \\ (Department of Geology and Geophysics, Geophysical and Polar Research Center, University \\ of Wisconsin-Madison, Lewis G. Weeks Hall, I2I5 W. Dayton Street, Madison, \\ Wisconsin 53706, U.S.A.)
}

\begin{abstract}
Compressional wave velocity gradients at 43 of 50 Antarctic traverse stations plot as sequences of straight lines on semilogarithmic graph paper. Intersections of the lines appear to correlate with depths at which the predominant metamorphic mechanism in polar snow changes. The seismic pattern supports a three-layer interpretation of snow densification. The base of the upper layer $(8.4 \pm 2.3 \mathrm{~m})$ corresponds to the "critical depth" of Anderson and Benson ( 1963 ) at which snow grains settle into a "random closepacked" arrangement. The base of the lower layer may correspond to the firn : ice transition depth, but more data are needed to confirm this conclusion. It is unclear what densification phenomenon is marked by the base of the middle layer $(27.7 \pm 4.4 \mathrm{~m})$. The distinction between the middle and lower layers tends to disappear and the velocity gradient at a fixed depth increases as mean annual accumulation decreases.

RÉsumÉ. Recherches sur la neige polaire par les gradients de vitesses de propagation des ondes sismiques. Les gradients de vitesse de propagation des ondes de pression dans 43 des $5^{\circ}$ stations de la traversée de l'Antarctique, dessinent des suites de lignes droites sur un papier semilogarithmique. Les intersections des lignes semblent être liées aux profondeurs auxquelles change le mécanisme prédominant de métamorphose dans la neige polaire. Le comportement sismique suggère une interprétation du tassement de la neige comme un phénomène à trois niveaux. La base du niveau supérieur $(8,4 \pm 2,3 \mathrm{~m})$ correspond à la profondeur critique de Anderson et Benson (1963) à laquelle les grains de neige se tassent dans l'arrangement aléatoire le plus compact. La base du niveau inférieur correspond peut-être à la limite névé-glace, mais on doit avoir plus de données pour confirmer cette conclusion. On ne peut dire definitivement à quel processus de densification correspond la base du niveau médian $(27,7 \pm 4,4 \mathrm{~m})$. La distinction entre les milieux median et inférieur tend à disparaître et le gradient de vitesse à une profondeur donnée s'accroît lorsque l'accumulation annuelle moyenne diminue.
\end{abstract}

Zusammenfassung. Untersuchung von polarem Schnee mit Hilfe seismischer Geschwindigkeilsgradienten. Die Geschwindigkeitsgradienten von Kompressionswellen an 43 von 50 Stationen in antarktischen Profilen ergeben, auf halblogarithmischem Papier aufgetragen, eine Folge von geraden Linien. Die Schnittpunkte der Geraden scheinen mit den Tiefen, in denen sich der vorherrschende metamorphische Mechanismus im polaren Schnee ändert, korreliert zu sein. Das seismische Muster legt cine Drei-Schichten-Interpretation bei der Schneeverdichtung nahe. Die Basis der oberen Schicht $(8,4 \pm 2,3 \mathrm{~m})$ entspricht der ,kritischen Tiefe" von Anderson und Benson (1963), in der Schneekörner sich in dichtester Packung anordnen. Die Basis der unteren Schicht könnte der Tiefe des Überganges von Firn zu Eis entsprechen, doch muss diese Annahme durch weitere Daten erhärtet werden. Es bleibt unklar, welches Verdichtungsphänomen sich in der Basis der mittleren Schicht $(27,7 \pm 4,4 \mathrm{~m})$ aüssert. Mit abnehmender mittlerer Jahresakkumulation neigt der Unterschied zwischen der mittleren und unteren Schicht zum Verschwinden, während der Geschwindigkeitsgradient in einer bestimmten Tiefe zunimmt.

\section{INTRODUCTION}

Exponential functions of the form, $\mathrm{d} V_{\mathrm{p}} / \mathrm{d} z=\left(\mathrm{d} V_{\mathrm{p}} / \mathrm{d} z\right)_{0} \mathrm{e}^{-\gamma z}$, where $\left(\mathrm{d} V_{\mathrm{p}} / \mathrm{d} z\right)_{0}$ and $\gamma$ are constants, have been used successfully to approximate segments of curves of compressional wave velocity gradient $\mathrm{d} V_{\mathrm{p}} / \mathrm{d} z$ versus depth $z$ on the ice sheets of Greenland (Brockamp and Pistor, [1968]) and of Antarctica (Kohnen and Bentley, r 973). Kohnen and Bentley correlate the depths at which the constants change at old and new "Byrd" stations with significant depths in the densification process of the firn. They suggest that sequences of exponential approximations might be used generally to relate seismic velocity gradients to glaciological parameters and to densification mechanisms. Accordingly, a general study of short refraction data from over-snow traverses throughout Antarctica has been undertaken to seek relationships between P-wave velocity gradients and accumulation, temperature, and the structure and metamorphism of polar snow cover.

\footnotetext{
- Contribution No. 300 of the Geophysical and Polar Research Center, University of Wisconsin-Madison.
} 

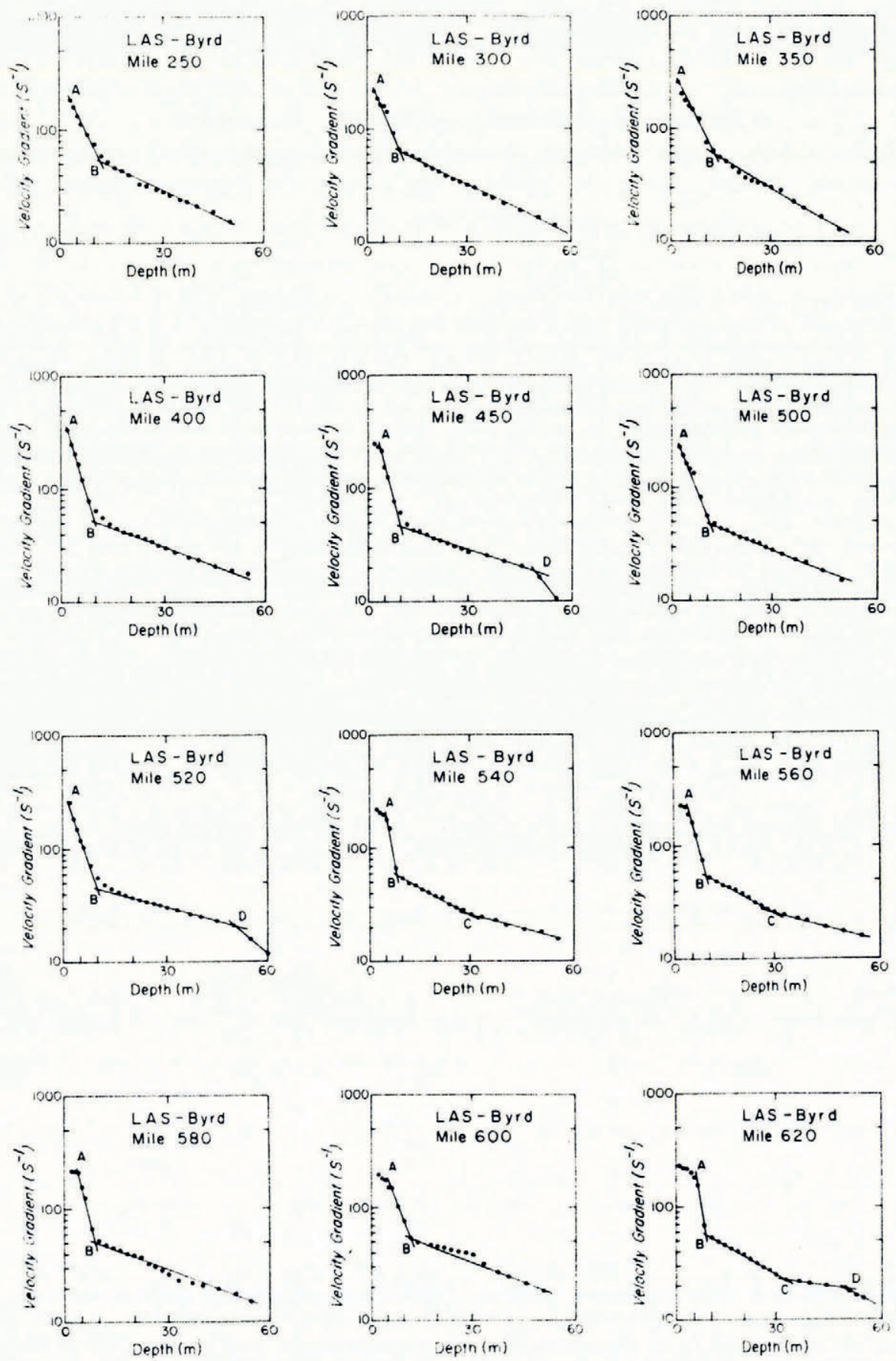

Fig. I. Part $I$. 

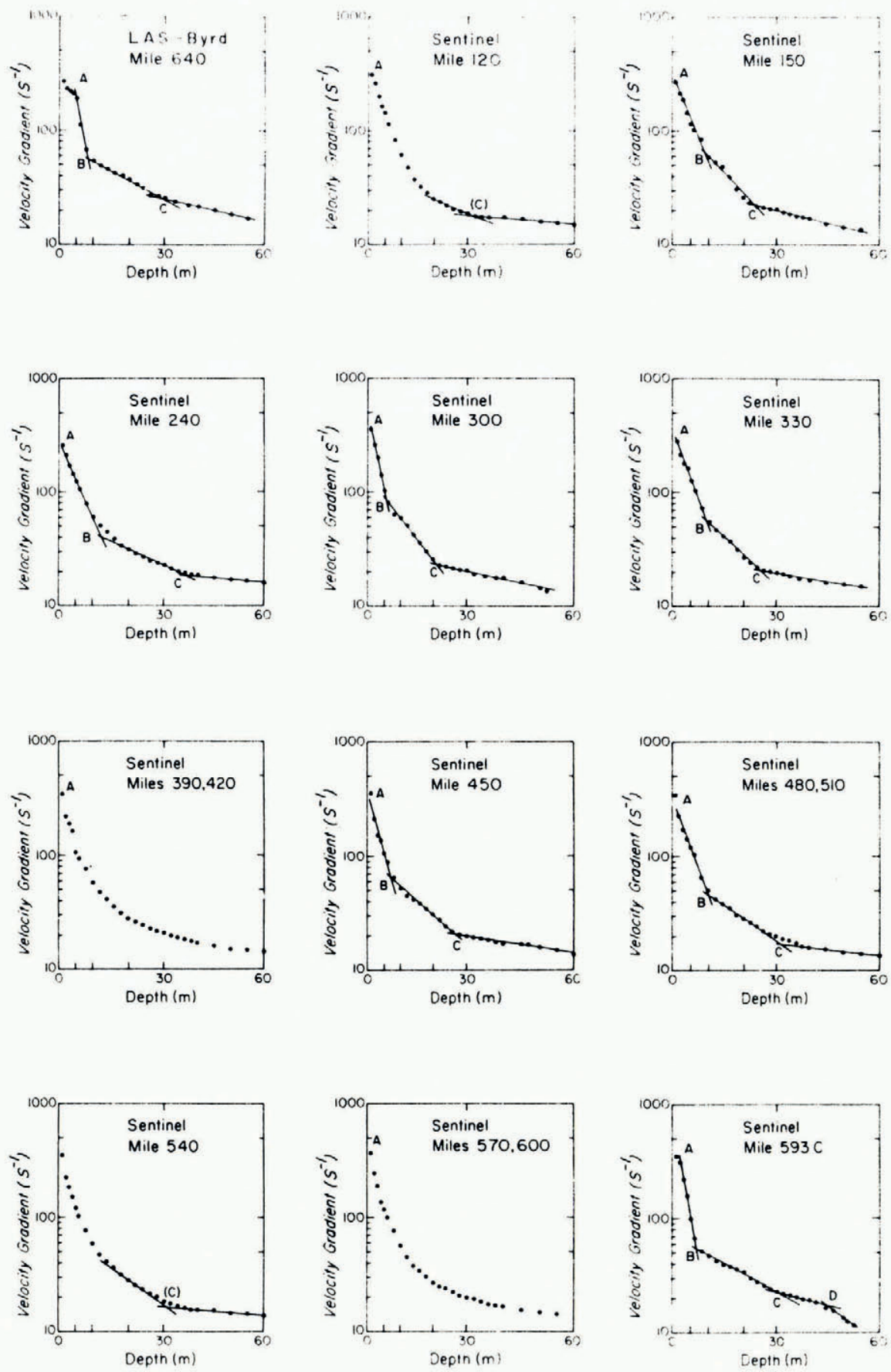

Fig. I. Part 2. 

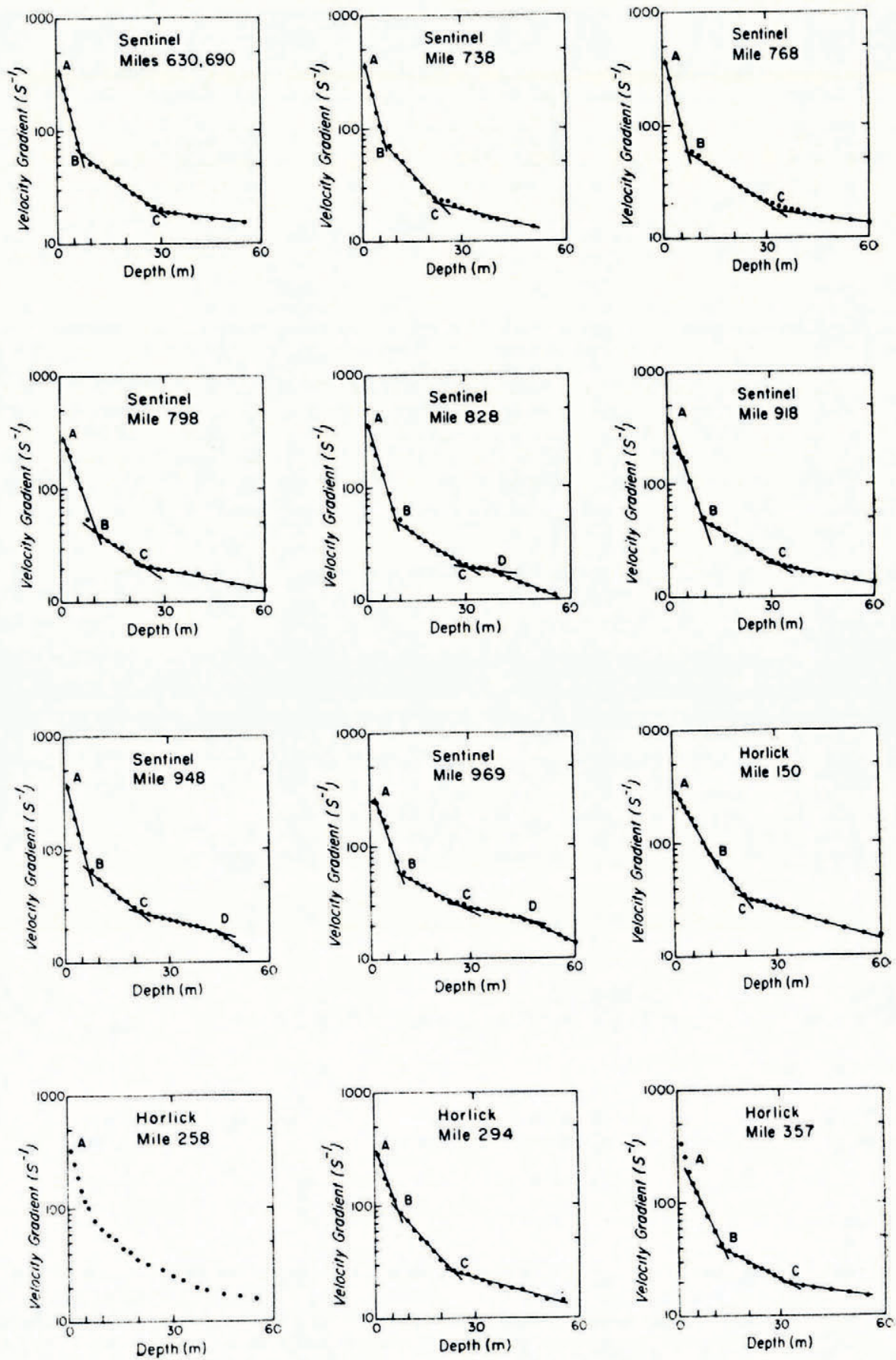

Fig. 1. Parl 3. 

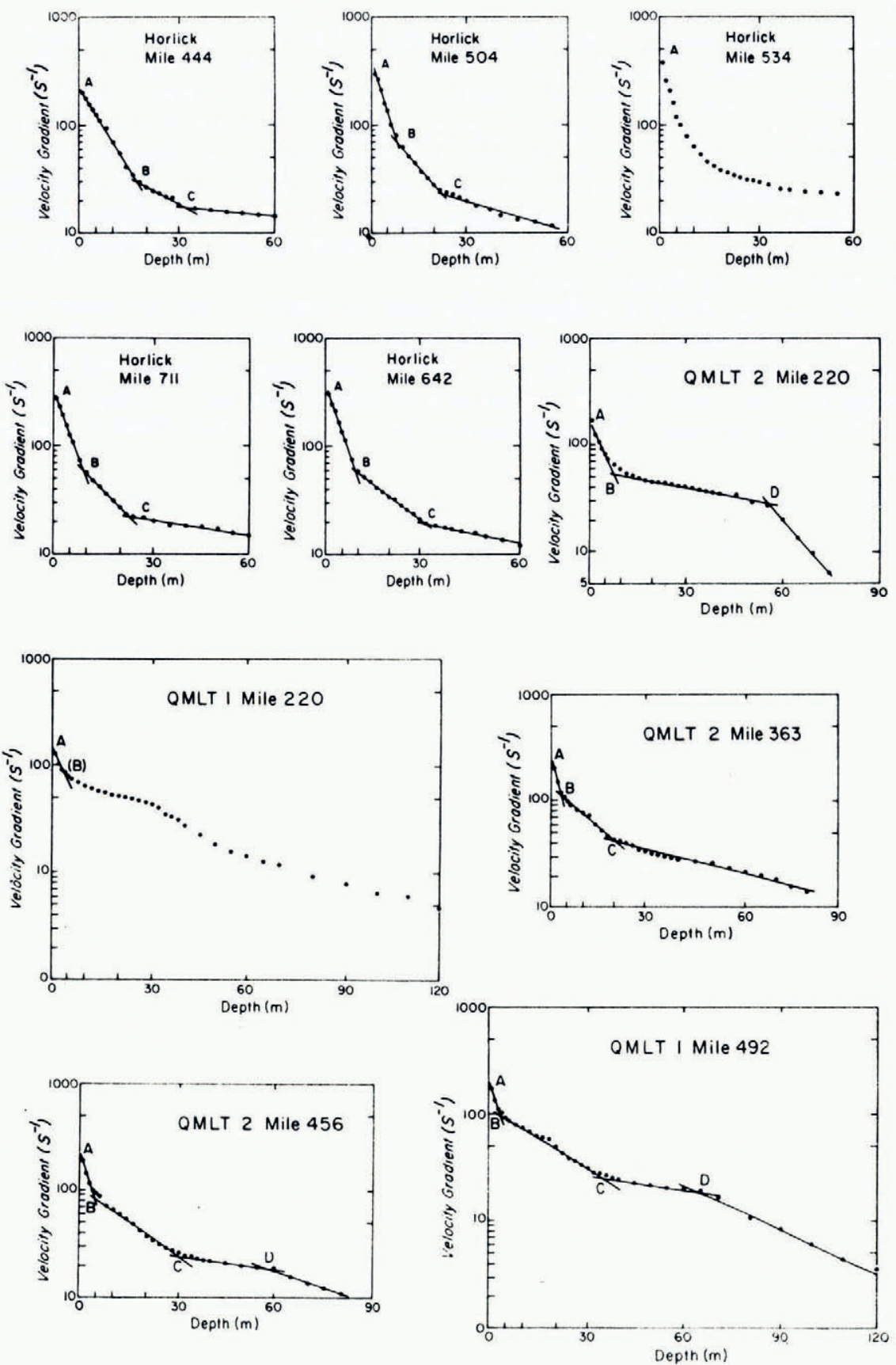

Fig. r. Part 4.

Fig. I. Compressional wave velocity gradient versus depth at seismic stations along the Little America-Byrd Traverse, 1956-57, Sentinel Traverse, 1957-58, Horlick Traverse, 1958-59, Queen Maud Land Traverse 1, 1964-65, and Queen Maud Land Traverse 2, $1965-66$. 


\section{Results}

Graphs of $\mathrm{d} V_{\mathrm{p}} / \mathrm{d} z$ versus $z$ have been constructed on semilogarithmic paper for short refraction velocity-depth data from fifty locations in Antarctica (Fig. 1). The following oversnow traverses are represented: Little America-Byrd Traverse, 1956-57; Sentinel Traverse, 1957-58; Horlick Traverse, 1958-59; Queen Maud Land Traverse I, 1964-65; and Queen Maud Land Traverse 2, $1965-66$. Individual stations are listed in Table I together with pertinent glaciological data and with geophysical data to be explained below. The maximum depth $z_{\max }$ sampled by each short refraction profile is a function of the length of the profile and varies from $50 \mathrm{~m}$ to $65 \mathrm{~m}$ along the West Antarctic traverses and from $80 \mathrm{~m}$ to $155 \mathrm{~m}$ along the East Antarctic traverses.

The plots may be divided fundamentally into two classes: type (a), fitted well by one straight line over the depth interval, $\approx 10 \mathrm{~m}-\approx 50 \mathrm{~m}$, and hence similar to the new "Byrd" station graph of Kohnen and Bentley (1973, fig. 2); and, type (b), fitted well by not one but two straight lines over this interval. An additional straight-line segment appears at the lower ends of a few of the graphs. Depths of intersections of straight lines fitted to the graphs are

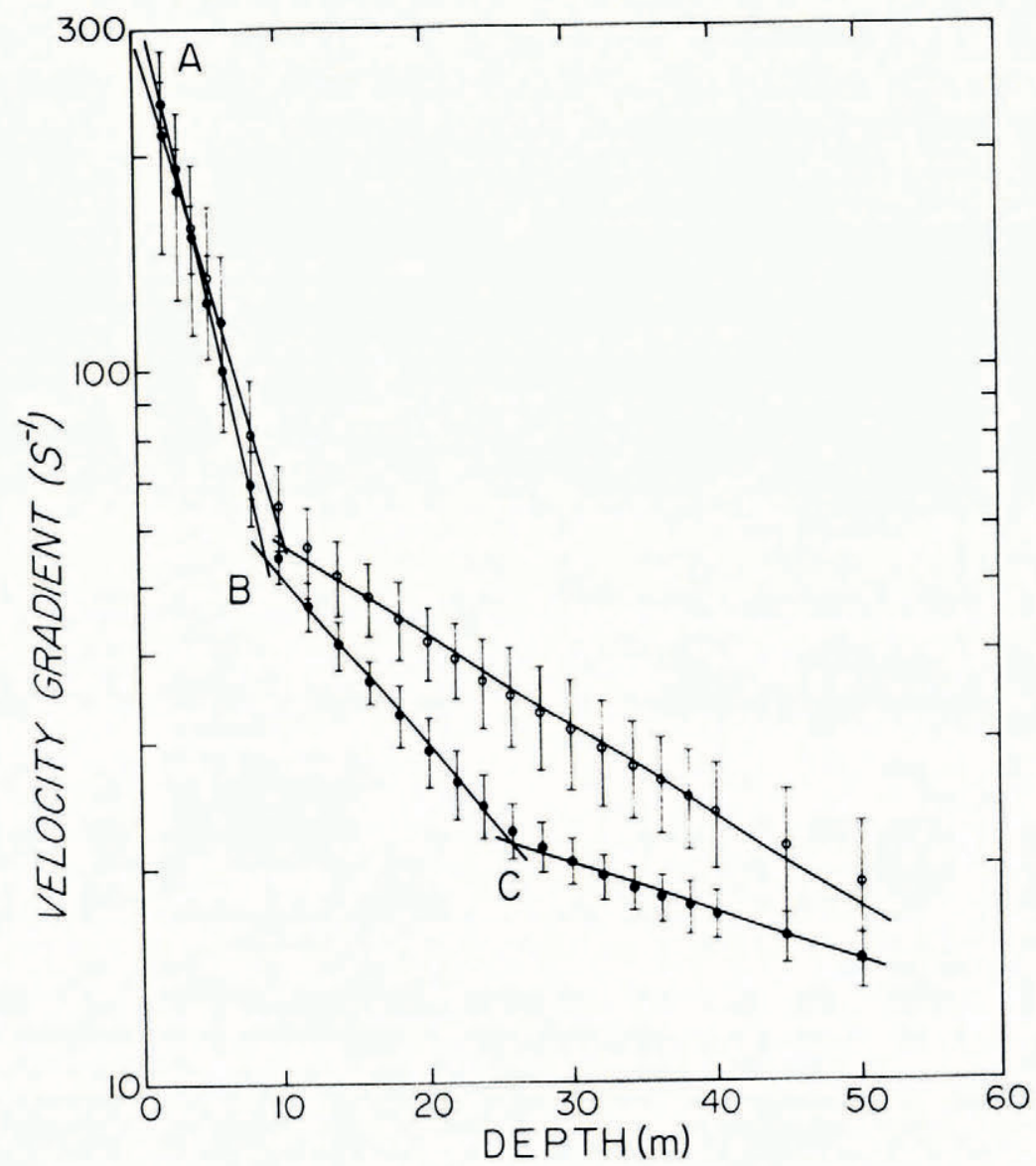

Fig. 2. Mean compressional wave velocity gradient versus depth at seismic stations in Antarctica. mean annual accumulation $>160 \mathrm{~kg} \mathrm{~m}^{-2}$ year $\left(19\right.$ stations, $b=274 \pm 96 \mathrm{~kg} \mathrm{~m}^{-2}$ year $\mathrm{r}^{-1}$ ). $\bigcirc$ mean annual accumulation $<160 \mathrm{~kg} \mathrm{~m}^{-2}$ year (I6 stations, $b=96 \pm 49 \mathrm{~kg} \mathrm{~m}^{-2}$ year $^{-1}$ ). 
Table I. Geophysical and glaciological data for selected seismic stations in Antarctica

\begin{tabular}{|c|c|c|c|c|c|c|c|c|}
\hline Station & & $\begin{array}{c}\mathbf{B} \dagger \\
\mathbf{m}\end{array}$ & $\begin{array}{c}\mathrm{C} \dagger \\
\mathrm{m}\end{array}$ & $\begin{array}{c}\mathrm{D} \dagger \\
\mathrm{m}\end{array}$ & $\underset{m}{z_{\max } \dagger}$ & Tupe & $\begin{array}{l}T_{+}^{+} \\
{ }^{\circ} \mathbf{C}\end{array}$ & $\mathrm{kg} \mathrm{m}^{-2}{ }^{b_{+}^{\dagger}}$ \\
\hline & 250 & II & - & - & 50 & a & $-24 \cdot 7$ & 154 \\
\hline & 300 & 10 & - & - & 55 & $\mathbf{a}$ & -25.9 & 146 \\
\hline & 350 & 12 & - & - & 50 & a & -24.0 & 94 \\
\hline & 400 & 10 & - & - & 60 & a & -23.9 & 102 \\
\hline & $45^{\circ}$ & 10 & - & 49 & 55 & a & -25.6 & 149 \\
\hline & 500 & II & - & - & 55 & a & -25.8 & 116 \\
\hline Little America-Byrd Traverse Mile & 520 & 10 & - & 50 & 60 & a & -27.2 & 116 \\
\hline & 540 & 9 & 30 & - & 55 & b & -27.6 & 137 \\
\hline & 560 & 9 & 29 & - & 55 & b & -28.1 & 120 \\
\hline & 580 & 9 & - & - & 55 & a & -30.1 & 119 \\
\hline & boo & II & - & - & 55 & a & -30.1 & 123 \\
\hline & 620 & 8 & 23 & 50 & 55 & b & -31.6 & 189 \\
\hline & $\begin{array}{l}640 \\
120\end{array}$ & & 30 & - & bo & b & NA & NA \\
\hline & 120 & NE & $\left(3^{2}\right)$ & & 60 & (b) & -28.5 & 310 \\
\hline & 150 & 9 & 24 & $\bar{z}$ & 60 & b & $\begin{array}{l}-28.0 \\
-26.5\end{array}$ & 410 \\
\hline & $\begin{array}{l}240 \\
300\end{array}$ & $\begin{array}{r}12 \\
6\end{array}$ & $\begin{array}{l}36 \\
21\end{array}$ & 二 & 65 & b & $\begin{array}{l}-20.5 \\
-25.4\end{array}$ & NA \\
\hline & 330 & 9 & 25 & - & $\begin{array}{l}55 \\
60\end{array}$ & b & $\begin{array}{l}-25.4 \\
-25.7\end{array}$ & $\begin{array}{l}430 \\
440\end{array}$ \\
\hline & 390 & NP & $\mathrm{NP}$ & - & 65 & & -27.2 & $\mathrm{NA}^{\circ}$ \\
\hline & 420 & NP & NP & - & 65 & & -27.6 & NA \\
\hline & 450 & 7 & 27 & - & 65 & b & -28.5 & 394 \\
\hline & 480 & Io & $3^{i}$ & - & 60 & b & -29.9 & 389 \\
\hline & 510 & 10 & $3^{1}$ & - & 60 & b & $-29 \cdot 9$ & 321 \\
\hline & 540 & NP & (31) & - & $6 o$ & (b) & $-29 \cdot 4$ & 280 \\
\hline Sentinel Traverse Mile & 570 & NP & NP & - & 60 & & -27.5 & 288 \\
\hline & $593 \mathrm{C}$ & 6 & 30 & 45 & 55 & b & -27.0 & NA \\
\hline & 600 & NP & NP & - & 60 & & -28.3 & 237 \\
\hline & 630 & 7 & 29 & - & 60 & b & -31.8 & 200 \\
\hline & 690 & 7 & 29 & - & 60 & b & -32.7 & 203 \\
\hline & $73^{8}$ & 7 & 23 & - & 55 & b & -34.2 & $19^{8}$ \\
\hline & 768 & 7 & 33 & - & 60 & b & -34.5 & 167 \\
\hline & $79^{8}$ & 11 & 24 & - & 60 & b & -32.8 & 201 \\
\hline & 828 & 9 & 30 & 36 & 55 & b & -33.7 & 179 \\
\hline & 918 & Io & $3^{2}$ & - & 60 & b & -30.3 & 191 \\
\hline & 948 & 7 & 21 & 45 & 55 & b & -30.1 & 186 \\
\hline & 969 & 9 & 27 & 46 & 60 & b & -29.4 & NA \\
\hline & 150 & 10 & 20 & - & 65 & b & -24.9 & NA \\
\hline & 258 & NP & NP & - & 60 & & -25.4 & NA \\
\hline & 294 & 8 & 23 & - & 60 & b & -24.4 & NA \\
\hline & 357 & 12 & 33 & - & 60 & b & -24.8 & NA \\
\hline Horlick Traverse Mile & 444 & 17 & $3^{2}$ & - & 65 & b & -30.3 & NA \\
\hline & 504 & 8 & 23 & - & 60 & b & -37.1 & NA \\
\hline & 534 & NP & NP & - & 60 & & -34.2 & NA \\
\hline & 642 & 9 & 32 & - & 65 & b & -37.5 & NA \\
\hline & & 9 & 23 & - & 65 & b & -29.9 & NA \\
\hline Queen Maud Land Traverse I Mile & $220^{* * *}$ & 4 & - & - & 155 & & -51.0 & $4^{0-50}$ est. \\
\hline & $49^{* * *}$ & 4 & 35 & 64 & 145 & b & -49.0 & $40-50$ est. \\
\hline & $220^{* * *}$ & 8 & & 55 & 80 & a & -47.0 & 32 \\
\hline Leen Maud Land Traverse 2 & $363^{* *}$ & 3 & 20 & $\overline{50}$ & 85 & $\begin{array}{l}b \\
b\end{array}$ & $\begin{array}{l}-46.0 \\
-48.0\end{array}$ & $\begin{array}{r}24 \\
6\end{array}$ \\
\hline
\end{tabular}
(1961).

* locations of Little America-Byrd, Sentinel, and Horlick stations are published in Bentley and Ostenso $\dagger$ explained in text.

from Kojima (1964) except for Queen Maud Land Traverses

* velocity-depth data from Beitzel (1971), temperature data from Kane (1970), accumulation data from Picciotto and others (1970).

est. estimated from data at adjacent stations.

NA not available.

- not present.

NP not picked owing to inconclusive data. 
listed in Table I under letter headings which match the lettering of Figure I. At seven stations no depths of intersection have been picked since the data there are not fitted well by straight lines. The mean depths to $B$ and $C$ are $\bar{z}_{\mathrm{B}}=8.4 \pm 2.3 \mathrm{~m}$ and $\bar{z}_{\mathrm{C}}=27.7 \pm 4.4 \mathrm{~m}$ respectively. No mean depth to $\mathrm{D}$ is given since it would be strongly biased by the limited sampling depth, which clearly cuts off almost all values greater than about $50 \mathrm{~m}$.

Both the velocity gradient and the occurrence of intersection $\mathrm{C}$ depend upon the mean annual accumulation, $\dot{b}$. The dependence is illustrated in Figure 2. Depth-velocity gradient data from those stations for which measurements of accumulation are available have been arbitrarily divided into two approximately equal groups by separation according to whether $b>160 \mathrm{~kg} \mathrm{~m}^{-2}$ year $^{-1}$ (19 stations, $b=274 \pm 96 \mathrm{~kg} \mathrm{~m}^{-2}$ year $^{-1}$ ) or $b<160 \mathrm{~kg} \mathrm{~m}^{-2} \mathrm{year}^{-1}$ ( 6 stations, $b=96 \pm 49 \mathrm{~kg} \mathrm{~m}^{-2}$ year-1). Mean values and standard deviations of the velocity gradients of the two groups are plotted in Figure 2. It is apparent ( 1 ) that values of $P$-wave velocity gradient itself are low at stations where accumulation is high, and (2) that the change in slope at intersection $\mathrm{C}$ increases with increased accumulation. The mean values of the group for which $b>160 \mathrm{~kg} \mathrm{~m}^{-2}$ year $^{-1}$ have been divided at $\bar{z}_{\mathrm{B}}$ and $\bar{z}_{\mathrm{C}}(8.4$ and $27.7 \mathrm{~m}$ ), and straight lines have been fitted to the resulting linear segments by the technique of least squares. The other group has been divided only at $\bar{z}_{\mathrm{B}}$ as $\mathrm{C}$ is not obviously present, although a change in slope is suggested. The constants $\left(\mathrm{d} V_{\mathrm{p}} / \mathrm{d} z\right)_{0}$ and slopes $\gamma$ of the least-squares lines are given in Table II.

Table II. Parameters of least-squares lines through data

\begin{tabular}{crc} 
Line & \multicolumn{1}{c}{$\left(\frac{d V_{\mathrm{p}}}{d z}\right)_{0}$} & \multicolumn{1}{r}{} \\
& $\mathrm{s}^{-1}$ & \multicolumn{1}{c}{$\mathrm{m}^{-1}$} \\
A-B $\left(b<160 \mathrm{~kg} \mathrm{~m}^{-2}\right.$ year $\left.^{-1}\right)$ & $292.9 \pm 1.0$ & $0.15^{8} \pm 0.005$ \\
B-end $\left(b<160 \mathrm{~kg} \mathrm{~m}^{-2}\right.$ year $\left.^{-1}\right)$ & $77.5 \pm 1.0$ & $0.030 \pm 0.001$ \\
A-B $\left(b>160 \mathrm{~kg} \mathrm{~m}^{-2}\right.$ year $\left.^{-1}\right)$ & $354.2 \pm 1.0$ & $0.208 \pm 0.004$ \\
B-C $\left(b>160 \mathrm{~kg} \mathrm{~m}^{-2}\right.$ year $\left.^{-1}\right)$ & $90.0 \pm 1.0$ & $0.055 \pm 0.002$ \\
C-end $\left(b>160 \mathrm{~kg} \mathrm{~m}^{-2}\right.$ year $\left.^{-1}\right)$ & $32.8 \pm 1.0$ & $0.016 \pm 0.001$
\end{tabular}

A bilinear regression was performed on the data in Table $I$ to test the dependence of depths to $\mathrm{B}\left(z_{\mathrm{B}}\right)$ and $\mathrm{C}\left(z_{\mathrm{C}}\right)$ on mean annual accumulation and mean annual temperature $\boldsymbol{T}$. The regression equations are:

$$
z_{\mathrm{B}}=(0.015 \pm 0.004) b-(0.16 \pm 0.03) T
$$

and

$$
z_{\mathrm{C}}=(0.025 \pm 0.007) b-(0.67 \pm 0.05) T
$$

The partial and multiple correlation coefficients for Equations ( 1 ) and (2) are given in Table

\begin{tabular}{|c|c|c|c|}
\hline & $b$ & $T$ & $b, T$ \\
\hline$z_{\mathrm{B}}$ & $\begin{array}{l}0.55^{2} \\
0.625\end{array}$ & $\begin{array}{l}0.737 \\
0.940\end{array}$ & $\begin{array}{l}0.927 \\
0.984\end{array}$ \\
\hline
\end{tabular}
III.

\section{Discussion}

An interval of constant slope on plots of $\ln \left(\mathrm{d} V_{\mathrm{p}} / \mathrm{d} z\right)$ versus $z$ probably reflects the predominance of a particular metamorphic process in the corresponding depth interval, breaks occurring at depths where the predominant metamorphic mechanism changes. Upon comparing their seismic results at old and new "Byrd" stations with direct observations on ice 
cores made by Gow (1965, 1970), Kohnen and Bentley (1973) correlate the breaks B and D with, respectively, the "critical depth" of Anderson and Benson (1963) and the depth where firn becomes impermeable. The "critical depth" is the limit ("close random packing") beyond which grain packing is no longer an effective densification mechanism, and occurs when density equals about $0.55 \mathrm{Mg} \mathrm{m}^{-3}$ (Anderson and Benson, 1963, p. 400). The present results appear to conform with that correlation for $\mathrm{B}$.

$\mathrm{D}$ is present on only ten graphs, presumably owing to insufficient profile length. Profile lengths at West Antarctic stations are not long enough conclusively to define D breaks below $50 \mathrm{~m}$. At three inland sites in Antarctica, exclusive of the high East Antarctic plateau, where drilling has been done to sufficient depth, the firn-ice transition is observed or estimated to lie at $64 \mathrm{~m}$ (old "Byrd"; Gow, 1965,) $56 \mathrm{~m}$ (new "Byrd", Gow, 1970), and $58 \mathrm{~m}$ ("Southice", Gow, 1968). Thus, only unusually shallow D breaks would be expected to appear in the graphs of Figure $\mathrm{I}$, as is indeed the case. Whether those D breaks that do appear represent truly shallow firn-ice boundaries or inaccuracy in the seismic method of determination is impossible to say for certain. The close correlation cited by Kohnen and Bentley (1973) suggests, however, that the former may well be the case. The depths to $\mathrm{D}$ at the three sites on the Queen Maud Land Traverses $(55 \mathrm{~m}-64 \mathrm{~m})$ are much shallower than estimated for the firn-ice boundary at the South Pole (110 m; Gow, 1968) and "Plateau" station (16o m; Gow, 197I). However, temperatures at the traverse sites are substantially warmer than at "Plateau" $\left(-57^{\circ} \mathrm{C}\right)$, and accumulation rates are substantially less than at the South Pole (70 $\mathrm{kg} \mathrm{m}^{-2}$ year $^{-1}$; Gow, 1968). Further direct comparisons between seismic and drilling results are clearly needed.

The results of the current study indicate that $\mathrm{C}$ is a real and widespread seismic phenomenon in Antarctica. The glaciological significance of the appearance of $\mathbf{C}$ is that it suggests that two distinct mechanisms successively dominate the metamorphic process between the depth of closest-packing of snow grains and the firn-ice boundary. An interesting parallelism exists between the appearance of $\mathrm{C}$ and unconfined compressive creep tests performed by Ramseier and Pavlak (1964) and Mellor and Smith (1967). Upon comparing the depthdensity curve presented by Gow (1968) for the $309 \mathrm{~m}$ drill hole at old "Byrd" station with depths to $\mathrm{C}$ listed in Table $\mathrm{I}$, we estimate that $\mathrm{C}$ occurs in the density range, $0.62-0.68$ $\mathrm{Mg} \mathrm{m}^{-3}$. The approximate density range between B and $\mathrm{C}\left(0.55^{-0.65} \mathrm{Mg} \mathrm{m}^{-3}\right)$ corresponds to the density range $\left(0.53-0.64 \mathrm{Mg} \mathrm{m}^{-3}\right)$ in which Mellor and Smith (1967) found that compressive viscosity was nearly independent of density during unconfined compressive creep tests on snow samples. Ramseier and Pavlak (1964) presented a similar curve of compressive viscosity versus density for snow from the South Pole which shows breaks at 0.47 and $0.625 \mathrm{Mg} \mathrm{m}^{-3}$. This correlation between seismic results and creep tests supports the interpretation of the seismic horizon as a real glaciological phenomenon; it should be tested by obtaining cores from locations where $\mathrm{C}$ is known to occur.

\section{Acknowledgements}

This work was supported by NSF grants GV-27044 and GV-32873.

MS. received 15 August 1973 and in revised form I April 1974

\section{REFERENCES}

Anderson, D. L., and Benson, C. S. 1963. The densification and diagenesis of snow. (In Kingery, W. D., ed. Ice and snow; properties, processes, and applications: proceedings of a conference held at the Massachusetts Institute of Technology, February 12-16, 1962. Cambridge, Mass., The M.I.T. Press, p. 391-411.)

Beitzel, J. E. 1971. Geophysical exploration in Queen Maud Land, Antarctica. (In Crary, A. P., ed. Antarctic snow and ice studies. II. Washington, D.C., American Geophysical Union, p. 39-87. (Antarctic Research Series, Vol. 16.)) 
Bentley, C. R., and Ostenso, N. A. 1961. Glacial and subglacial topography of west Antarctica. Journal of Glaciology, Vol. 3, No. 29, p. 882-911.

Brockamp, B., and Pistor, P. [1968.] Ein beitrag zur seismischen Erforschung der Struktur des grönländischen Inlandeises. Polarforschung, Bd. 6, Jahrg. 37, Ht. 1-2, 1967, p. 133-46.

Gow, A. J. 1965. The ice sheet. (In Hatherton, T., ed. Antarctica. London, Methuen, p. 221-58.)

Gow, A. J. 1968. Deep core studies of the accumulation and densification of snow at Byrd station and Little America V, Antarctica. U.S. Cold Regions Research and Engineering Laboratory. Research Report 197.

Gow, A. J. 1970. Preliminary results of studies of ice cores from the $2164 \mathrm{~m}$ deep drill hole, Byrd station, Antarctica. (In [Union Géodésique et Géophysique Internationale. Association Internationale d'Hydrologie Scientifique.] [International Council of Scientific Unions. Scientific Committee on Antarctic Research. International Association of Scientific Hydrology. Commission of Snow and Ice.] International Symposium on Antarctic Glaciological Exploration (ISAGE), Hanover, New Hampshire, U.S.A., 3-7 September 1968, p. 78-9o.)

Gow, A. J. 1971. Depth-time-temperature relationships of ice crystal growth in polar glaciers. U.S. Cold Regions Research and Engineering Laboratory. Research Report 300.

Kane, H. S. 1970. A study of $10 \mathrm{~m}$ firn temperatures in central east Antarctica. (In [Union Géodésique et Géophysique Internationale. Association Internationale d'Hydrologie Scientifique.] [International Council of Scientific Unions. Scientific Committee on Antarctic Research. International Association of Scientific Hydrology. Commission of Snow and Ice.] International Symposium on Antarctic Glaciological Exploration (ISAGE), Hanover, New Hampshire, U.S.A., 3-7 September 1968, p. 165-74.)

Kohnen, H., and Bentley, C. R. 1973. Seismic refraction and reflection measurements at "Byrd" station, Antarctica. Journal of Glaciology, Vol. 12, No. 64, p. IOI-11.

Kojima, K. 1964. Densification of snow in Antarctica. (In Mellor, M., ed. Antarctic snow and ice studies. Washington, D. C., American Geophysical Union, p. 157-218. (Antarctic Research Series, Vol. 2.))

Mellor, M., and Smith, J. H. I967. Creep of snow and ice. (In Oura, H., ed. Physics of snow and ice: international conference on low temperature science. ... 1966. ... Proceedings, Vol. I, Pt. 2. [Sapporo], Institute of Low Temperature Science, Hokkaido University, p. 843-55.)

Picciotto, E. E., and others. 1970. Snow accumulation along the South Pole-Dronning Maud Land traverse, by E. [E.] Picciotto, W. de Breuck and G. Crozaz. (In [Union Géodésique et Géophysique Internationale. Association Internationale d'Hydrologie Scientifique.] [International Council of Scientific Unions. Scientific Committee on Antarctic Research. International Association of Scientific Hydrology. Commission of Snow and Ice.] International Symposium on Antarctic Glaciological Exploration (ISAGE), Hanover, New Hampshire, U.S.A., 3-7 September

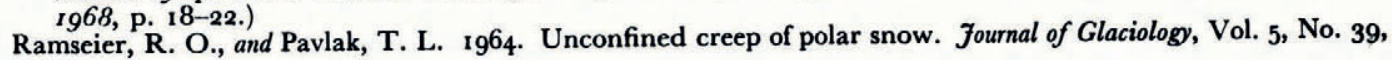
p. 325-32. 